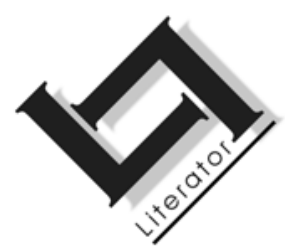

\title{
Riviere as identiteitskonstrueerders
}

\author{
S. Meyer
}

Vakgroep: Afrikaans

Fakulteit Opvoedingswetenskappe

Potchefstroomkampus

Noordwes-Universiteit

POTCHEFSTROOM

E-pos: Meyer.Susan@nwu.ac.za

\section{Abstract \\ Rivers and the construction of identity}

The collection of youth memories "Met 'n eie siekspens" (Engela van Rooyen) and the novel "Manaka: plek van die horings" (Pieter Pieterse) complement each other as literary embodiments of the phenomenon that human life and identity are influenced by an aspect of the characters' natural environment, namely the river. This article focuses on the nature and extent of the influence of rivers on the development of identity in characters in these two works. In "Met 'n eie siekspens" the formative role of the Orange River is connected with a complex relationship between man and river in which elements of devotion collide with those of enslavement. The values taught by the river and its surroundings are core components of the characters' identities. In "Manaka: plek van die horings", the main character's dream of a life on the Zambezi is part of his identity, in that it embodies selfrealisation and has directed his thinking and self-image since childhood. The river and its surroundings, however, later on also play an important role in the re-interpretation of his life goal and the acquisition of a wider understanding of his true identity. This investigation underlines the importance of research into the portrayal of the relationship between man and nature within the broader field of study in which the portrayal of matters of identity in Afrikaans literature is investigated. 


\section{Opsomming}

\section{Riviere as identiteitskonstrueerders}

Die bundel jeugherinneringe "Met 'n eie siekspens" (Engela van Rooyen) en die roman "Manaka: plek van die horings" (Pieter Pieterse) vul mekaar aan as literêre vergestalting van die verskynsel dat die menslike lewe en identiteit beïnvloed word deur 'n aspek van die karakters se natuurlike omgewing, naamlik die rivier. Hierdie ondersoek fokus op die aard en omvang van die invloed van riviere op die identiteitsvorming van karakters in hierdie twee prosawerke. In "Met 'n eie siekspens" hou die vormende rol van die Oranjerivier verband met 'n komplekse verbintenis tussen mens en rivier waarbinne elemente van verknogting bots met dié van verknegting. Die lewenswaardes wat die rivier en rivieromgewing die karakters leer, is kernkomponente van hulle identiteit. In "Manaka: plek van die horings" blyk die hoofkarakter se droom oor 'n lewe op die Zambezi deel te wees van sy identiteit deurdat dit selfrealisering behels en sy denke en selfbeskouing sedert kindsbeen rig. Die rivier en omgewing speel egter ook 'n sentrale rol in die latere herinterpretasie van sy lewensdoel en die verkryging van 'n breër begrip van sy ware identiteit. Die ondersoek onderstreep die belang van navorsing oor die uitbeelding van die verhouding tussen mens en natuur binne die groter studieveld waarin die uitbeelding van identiteitskwessies in die Afrikaanse letterkunde ondersoek word.

\section{Navorsingskonteks}

In Engela van Rooyen se bundel jeugherinneringe, Met ' $n$ eie siekspens (1994), wat in 2005 herdruk is, is die rivier 'n sterk saambindende faktor in die vertellings en kom die direkte inspeel van die rivier op die lewens en identiteit van die karakters aan die lig. In dieselfde jaar as die herdruk van Met 'n eie siekspens verskyn Manaka: plek van die horings (2005), die laaste roman uit die pen van Pieter Pieterse. Tematiese verskille ten spyt vul hierdie werk Van Rooyen s'n aan as literêre vergestalting van die verskynsel van identiteitsvorming in samehang met 'n bepaalde aspek van die karakters se natuurlike omgewing, naamlik die rivier.

Dit is verrassend dat die rol wat die rivier in karakters se lewenswerklikheid en in die konstruksie van identiteit ${ }^{1}$ in die 
Afrikaanse prosa speel nog nie indringend nagevors is nie, aangesien riviere so dikwels teenwoordig is in die werk van verskillende Afrikaanse skrywers. Die rivier word byvoorbeeld betrek in 'n hele korpus waterslangverhale waarna Jean Lombard in 'n studie getiteld Waterslangverhale in en rondom Afrikaans ${ }^{2}$ verwys, maar in hierdie navorsing ontvang die mens-rivier-relasie geen aandag nie. Die rivier is ook in mindere of meerdere mate prominent wanneer geskryf word oor sekere geografiese streke: in die werk van E. Kotze staan die streek tussen die Berg- en Oranjerivier aan die Weskus dikwels sentraal en in die oeuvres van Thomas Deacon en George Weideman word die benede-Oranje/Gariepgebied 3 in die Noord-Kaap aangetref. Hoewel ook geen navorsing oor die moontlike verband tussen die rivier en identiteitskonstruksie in enige van hierdie oeuvres gevind kan word nie, word in besprekings van Deacon en Weideman se werk wel enkele verwysings aangetref na die rivier wat in sekere tekste méér word as die blote ruimtelike gegewe, omdat dit ook metafories figureer. Van Manen (1999:7) beskou die veelvlakkige vertellings in Deacon se Anderkant die Troe-troe (1999), waarin die onverklaarbare as die doodeenvoudige beleef en oorvertel word, as die oorsteek van 'n rivier na "'n ander soort waarheid". Die hoofkarakter Thomas in Deacon se roman, Rooigrond (1997), beleef soveel innerlike stryd tussen die Christelike geloof en die tradisionele godsdiens van sy voorvaders dat hy homself nie meer as mens beleef nie, maar as 'n stuk hout wat deur die rivier uitgespoel is (Du Toit, 1997:6). In die bespreking van Weideman se prosa-oeuvre verwys Van Coller en Odendaal (1999:775) na die verhaal "Tuin van optelglas" (uit Tuin van klip en vuur, 1983) om die dominansie van die rivier ook op 'n ander vlak as die ruimtelike uit te wys. In hierdie verhaal roei Naas elke dag vir Janie veilig oor die groot rivier na die skool toe. Hoewel die rivier geen vrees by hom inboesem nie, is hy vasgevang in sy eie

waarvolgens die modaliteite van identiteit nie oorgaan in 'n invariante struktuur nie, maar lewenslank 'n proses- of aktiwiteitskarakter behou (Taljard 2002:43).

Lombard (1999:6) verwys na werke uit die ouer Afrikaanse literatuur, soos dié van G.R. von Wielligh, Eugéne Marais en Minnie Postma, sowel as na meer resente romans, onder andere Die eerste lewe van Adamastor (André P. Brink), Meraai van Rolbos (Charlotte de Beer), Die dagstêrwals (Johnita le Roux), Die donker melk van daeraad (George Weideman), In die omtes van die hart (Petra Muller), Rooigrond (Thomas Deacon) en lets goeds uit Verneukpan? (Elias P. Nel). 'n hele paar rivierwêrelde, van Hongarye tot Namibië en die Noord-Kaap. 
"maalstroom" (p. 80), soos sy huislike omstandighede op veelbetekenende wyse beskryf word.

Nog 'n teks waarin die rivier enersyds as natuurkrag en andersyds as sentrale metafoor funksioneer, is Morkel van Tonder se "Laingsburg"-roman, Die Vloed (1989). Weens die element van onvoorspelbaarheid word die rivier in hierdie roman metafoor vir menslike emosie. Weideman (1989:11) interpreteer die motto uit Job ("As 'n vloedramp skielik die dood bring, lag God oor die wanhoop van die onskuldiges") as suggestie van die groei en vloei van emosies, totdat natuur- en menslike kragte oorweldigend teenoor mekaar staan.

Skynbaar die enigste Afrikaanse prosateks waarin 'n duidelike verband tussen rivier en identiteit raakgesien is, is Die Stoetmeester (1993) van Etienne van Heerden. Wasserman (2000:42-43) wys op die rol van die rivier in die skep van 'n nuwe, postkoloniale identiteit en geskiedenis in hierdie roman, waar naamborde van strate vernoem na politici uit die apartheidsera saam met posbusse en lamppale wegspoel. In Antjie Krog se poësiebundel, Kleur kom nooit alleen nie, staan die kwessie van rivier en identiteit wel ook sentraal. In Louise Viljoen se bespreking van hierdie bundel fokus sy pertinent daarop: sy dui aan dat die Garieprivier en ook die Nigerrivier in Wes-Afrika gebruik word as metafoor vir die digter se opvatting van haar identiteit as Afrikaan (Viljoen, 2002:30, 42).

Dit bring ons by die poësie, ten opsigte waarvan die ondersoek na die rol van riviere vollediger blyk te wees. In 'n studie oor die Afrikagerigtheid in die Afrikaanse digkuns betrek Van der Merwe (1999:129-131) riviere as 'n betekenisvolle Afrikakode in die poësie van 1976 tot 1996. Sy toon aan dat in die tematiese ontginning van riviere in die Afrikaanse poësie die krag van riviere sentraal staan, onderskeidelik die skeppende en verwoestende aard daarvan, maar dan hoofsaaklik soos waargeneem ten opsigte van die omringende fisiese omgewing (Van der Merwe, 1999:129-131).4

$4 \quad$ In verskeie gedigte word die ontwrigting en verwoesting wat vloedwaters veroorsaak, uitgelig: "Klaagsang van die oewerboer" van George Weideman, "Vloed" van Donald Riekert en verskeie gedigte in Thomas Deacon se bundel Sand uit die son. Enkele gedigte fokus op die herskeppende krag van vloedwater op die fisiese omgewing of op die geduldige "ingenieurswerk" van riviere aan oewer en klip, byvoorbeeld "Vloed 6" van Thomas Deacon en "Reis na Namakwaland" deur T.T. Cloete (Van der Merwe, 1999:129-131). 
Dieselfde kragtige en skeppende teenwoordigheid van riviere is ook 'n kernaspek in Met 'n eie siekspens en Manaka: plek van die horings, waar twee van die grotes in Suidelike-Afrika - die Oranjerivier en die Zambezi onderskeidelik - by wyse van spreke deur die bladsye van die tekste vloei. Hier is die impak van die rivier egter direk op die karakters se identiteit te vind en nie meer grootliks op die uiterlike omstandighede en fisiese omgewing, soos Van der Merwe (1999:131) gevind het dit meestal in die Afrikaanse poësie gereflekteer word nie.

Hierdie ondersoek is daarop gerig om vas te stel wat die aard en omvang van die invloed van die rivier op die lewens en identiteit van die karakters in hierdie twee tekste is. Die verhouding wat uitgebeeld word tussen mens en rivier kom noodwendig ook onder die vergrootglas, aangesien die aard en intensiteit van hierdie verhouding saamhang met die mate van beïnvloeding wat die rivier op die karakters se menswees het.

Die aspekte van ruimte en identiteitskonstruksie waaroor dit in hierdie ondersoek gaan, staan volgens Castells (1997:7-8) en Viljoen (2002:21) in noue verband. Wasserman (2001:301) verklaar: "Identiteit word vasgestel - en hervasgestel - aan die hand van die belewing van ruimte ... Ruimte en identiteit staan in wisselwerking tot mekaar". Martin (1995:17) skenk in sy beskouing van identiteitsvorming aandag aan die verhoudings tot onderskeidelik die verlede, die ruimte en die kultuur: Die verhouding met ruimte behels onder meer die sosiale gebruik van die ruimte, die ruimte as 'n plek waar 'n individu of gemeenskap homself onderhou en handhaaf, en die ruimte as 'n plek van magsuitoefening (Martin, 1995:17). Al hierdie aspekte van ruimtebelewing, wat Martin relevant vind ten opsigte van identiteitskonstruksie, sal in die bespreking wat volg ter sprake kom. In die bespreking van Manaka: plek van die horings sal ook aangesluit word by White (1995:1) se standpunt dat nuwe ervarings in 'n nuwe ruimtelike omgewing mense se verwysingsraamwerk en opvattings beïnvloed en neerslag vind in veranderde of ontwikkelende uitbeeldings van ervaring en identiteit.

\section{Met'n eie siekspens}

Deur die herdruk van Met 'n eie siekspens in 2005 word die aandag van die leserspubliek weer gevestig op dié bundel waarmee Van Rooyen haar beeld as skrywer van "ontspanningslektuur" finaal 
gewysig het in die oë van kritici soos Kannemeyer (1994:34) en Venter (1995). 5

Die boekstawing van jeugervarings en herinnerings aan vervloë tye vorm 'n beduidende tradisie in die Afrikaanse literatuur. Daar is die talle kortverhale waarin Hennie Aucamp, Pirow Bekker, Henriëtte Grové, Chris Barnard, Petra Muller en ander skrywers spesifiek inisiërende jeugervarings verwerk het en waarna Malan (2004:189) verwys. Malan (2004:189) onderskei verder tussen biografiese herinneringstekste, kort jeugromans wat klaarblyklik op biografiese ervarings berus en allerlei publikasies wat eksplisiet as kroniek van 'n vergange jeug, of as dokument van 'n ouer volkskultuur opgeteken word en meestal deur die outeurs self uitgegee is. Smuts (2000:10) wys daarop dat daar, naas die voortsetting van die tradisionele herinneringsliteratuur in die negentigerjare, 6 ook langer tekste bestaan wat nie in die eng sin van die woord as herinneringsliteratuur bestempel kan word nie, maar waarin daar so 'n sensitiewe herskepping van ' $n$ verlede en ook 'n duidelike historiese verankering is dat dit 'n nuwe dimensie aan die begrip herinneringsliteratuur gee. 7

Hoewel Smuts (1997:3) meen dat die benadering van Met 'n eie siekspens nie opvallend van die ouer soort herinneringsliteratuur verskil nie, sal uit die ondersoek wat volg blyk dat hierdie bundel tog ook elemente bevat wat ver verwyderd is van die tradisionele herinneringskuns. Dit sal duidelik word dat die leser se resepsie van hierdie bundel ná die herdruk daarvan in 2005 waarskynlik kan verskil van die oorspronklike resepsie daarvan twaalf jaar tevore, op

5 Die bundel is destyds ontvang as "'n prosabydrae wat bo die streeksvertelling uitstyg" (Kannemeyer, 1994:34), "'n outobiografie met 'n digte betekenisstruktuur" (Venter, 1995), "'n storie wat geen mens onaangeroer kan laat nie" (Wybenga, 1994:8) en "een van die beste prosawerke wat die afgelope tyd in Afrikaans verskyn het" (Blignault, 1996:7). Volgens Smuts (2000:10) kan die groter status wat streek- en herinneringsliteratuur soos Met 'n eie siekspens in die jare negentig binne die literêre kanon verkry het, verklaar word deur die groeiende behoefte aan roots-literatuur in die onlangse tyd.

$6 \quad$ Smuts (1997:2) beskryf die tradisionele herinneringsliteratuur as hoofsaaklik korterige verhalende en essayistiese prosatekste waarin dikwels nostalgies teruggedink word aan 'n tydperk en persone wat onherroeplik tot 'n verbygegane era behoort, en met 'n verifieerbare outobiografiese inslag.

7 Smuts (2000:10) verwys hier veral na romans van Karel Schoeman (Verkenning en Verliesfontein) en Etienne van Heerder (Kikoejoe), asook na werke wat in die teken van groter verskuiwings in die Suid-Afrikaanse samelewing staan, soos Johann Botha se Groot vyf. 
grond van die verskillende sosio-politieke en ekonomiese kontekste waarbinne hierdie lesings gedoen word.

Vervolgens word die verhouding tussen mens en rivier wat deur die herinneringe in Met 'n eie siekspens onthul word, ondersoek en daarná kom die impak van die rivier op identiteitsaspekte onder die soeklig.

\subsection{Herinnering: "Die troewel water wat ons lewe is"}

Daar is verskillende kragte in 'n outobiografiese geskrif werksaam (Venter 1995:12). Eerstens die krag van herinnering, waardeur die lewe langs, uit en saam met die rivier in die omgewing van Kakamas in hierdie bundel uit Van Rooyen se kindertyd opgeroep word.

Met die terugskouende verwysing na Grootrivier8 as "die troewel water wat ons lewe is" (p. 1) $)^{9}$ word eerstens 'n besef van bestaansafhanklikheid gesuggereer en tweedens dat daar 'n element van troebelheid, 'n donker kant, in dié afhanklikheid verskuil is. Een van die skrywer se eerste gewaarwordinge as kind is dat "ons in sy buidel woon" (p. 1). Met die buidelbeeld word die rol van die rivier as versorger sentraal geplaas in die kinderbelewing. Die aspek van versorging word ook pertinent gestel: "Word jy in die nag wakker, hoor jy dié geruis, en jy raak weer houtgerus aan die slaap" (p. 1). Selfs wanneer ' $n$ vloedervaring later in die bundel beskryf word, is die indruk wat die herinnering oorheers "die half vreedsame gevoel dat die leeu wel brul, maar nooit sy kleintjies opvreet nie" (p. 222).

Grootrivier openbaar 'n toegeeflikheid wat strook met die aspekte van sorg en verdraagsaamheid: "Jy mag sy sandbanke betree, skeeflopende krappe bekyk ... Jy tel rivierklippe op" (p. 221). Daar is selfs sprake van 'n bepaalde affiniteit tussen Grootrivier en sy oewerbewoners - "'n grappie kan Grootrivier ook maak", onthou die skrywer (p. 222). Vervleg met die ervarings van verwondering oor die rivier (p. 222-223) lê egter ook die belewing van sy onbetwiste meesterskap: "Ná 'n uitmergelende staanwater ... kom die tyding: Grootrivier kom af ... Skrik. Ontsag. Onheilige opwinding" (p. 221). 'n Verbintenis van komplekse aard word deur hierdie vroegste,

8 Nêrens in die bundel word verwys na die Grootrivier nie - hy is Grootrivier, en daarmee word die ontsag vir die rivier as gepersonifieerde teenwoordigheid gestel. aangedui word, verwys na Van Rooyen (1994). 
teenstrydige belewings van die rivier deur die rivierkind gesuggereer.

\subsubsection{Verhouding van aanhanklikheid}

Vroeg in die bundel word die rivier reeds assosiatief verbind met die onmiddellike natuurlike omgewing. In 'n reeks opeenvolgende sinne op bladsy 1 knoop die skrywer haar kleintydherinnering aan Grootrivier stewig vas aan die groter landskap10 wat sy haar "Adamsland" noem: die kliprante, die erf, die kameelbome, die duinepad. Grootrivier word die versamelbegrip vir al die elemente in die landskap waarna sy later in haar lewe terughunker: die maan oor 'n wit werfpad, die wingerde, die waterwiele en kokerbome, die reuk van modderige water en droë lusern (p. 4). ${ }^{11}$

Ten grondslag van die verhouding van aanhanklikheid lê die rivier se gawes aan en sorg vir diegene wat in sy "buidel" leef. Uit dit wat Grootrivier bied, is 'n bestaan vir die skrywer en haar voorsate moontlik gemaak. Van Rooyen se "voormense" het ná die droogte van 1896-1897 langs die Benede-Oranje beland toe die NG Kerk 'n reddingsoord vir verarmdes op Kakamas geskep het - 'n plek waar uit die rivier 'n watervoor gegrawe moes word om besproeiingsboerderytjies op die been te bring (p. 6-7). Hierdie grootvoor is geslagte later steeds die "lewensaar" (p. 147), want: "Wat jy plant, moet jy aanhou natlei. Trek jy jou hand weg, vergaan alles, en die woestyn neem oor. So eenvoudig is die storie van die erflewe hier teen die Grootrivier" (p. 156).

Die rivier is voorsiener op die vlak van primêre behoeftes (p. 147148 ) - ook die huisvesting. Uit riet, "een van die goeie, gratis gawes

10 Die term landskap impliseer 'n fokus op aspekte van die natuurlike omgewing soos die geografie en plantegroei. Ek gebruik die term dus soos Viljoen (1998:74-77) dit doen wanneer sy onderskei tussen ruimte as neutrale term, plek as kultureel-gelade term en landskap, waar die fokus lê op die natuurlike omgewing, hoewel daar ook sprake kan wees van 'n historiese dimensie.

11 In die benaming Adamsland en die hunkerende beskrywings van die landskap word hier bevestiging gevind vir die standpunt binne die poststrukturalisme dat alle waargenome objekte in werklikheid konstruksies is op psigologiese, verbale of sosiale vlak, en dat landskap hierby ingesluit is. Die ekokritikus Belden Lane, soos aangehaal deur Scheese (2002:9), bevestig: "Landskap is eerstens 'n produk van die verbeelding, 'n gekonstrueerde wyse om die omgewing waar te neem ... Die spesifieke wyse waarop die toneel deur die waarnemer se oog geskik en geraam word, is 'n konstruksie van die verbeelding." Die waarneming van en herinnerings aan die rivieromgewing word vanuit die staanspoor gerig deur die skrywer se emosionele verbintenis daarmee. 
van Grootrivier aan sy oewerbewoners" (p. 102), word huise gebou. Uit die beskrywing van die huise word dit duidelik dat die oewerbewoners hierdie intiemste ruimtes beleef as 'n integrale deel van die groter rivierlandskap. Die riethuisie wat die skrywer as kind bewoon het, word nie beskryf met enige verwysing na die inhoudelike daarvan nie, maar as verlengstuk van die omgewing: die agterdeur "kyk rante toe", die stoepkamer "sit erf se kant toe" en die kaal stoepie is snags slaapplek onder die sterrehemel (p. 141). Alle deure staan dag en nag wawyd oop (p. 142) en deur die sinkdak word die elemente beleef: ' $n$ wolkie wat oortrek of 'n luggie wat stoot, laat die dak afkoel met 'n getik en geknal (p. 142). Hoe oud was die ou riethuis? vra die skrywer haar ma en ontvang 'n antwoord wat geformuleer is in terme van landskap, nie tyd nie: "Wie bodder met datums hier waar Grootrivier sedert eeue lê en asemhaal?" (p. 145).

In 'n bespreking van Met 'n eie siekspens wys Blignault (1996:8) op die verknooptheid van alle menslike ervarings langs die Grootrivier met die landskap. Alle belewenisse van arbeid hou verband met die pogings om "n bestaan aan sy oewers (te) probeer ontworstel" (p. 221): dis "alewig 'n gesukkel met leivore en akkerwalle en afsitte wat breek. Die duingrond sak soos nat suiker inmekaar" (p. 27). Herinnerings aan skool is herinnerings aan die steier van rivierriet waaronder die klas ingerig is (p. 127), aan eilandkinders wat soggens half verkluim per skuit aankom (p. 129) en die skaarste aan boeke, want "besproeiing is die hoogste wet" (p. 137). Ook in die godsdiensbelewing is die landskap teenwoordig: die skrywer herinner haar bidure in die rietsteierskooltjie en saamgevoude hande, "... in eerbied geknot soos óú vetplante" (p. 128); saans met boekevat of biduur bly hulle van Grootrivier se geruis bewus (p. 144). Selfs mense word beskryf in terme van die rivieromgewing en -bedrywighede: die skrywer se pa kon haar tweelingboeties dra "... soos wat jy twee waatlemoene sal dra, een onder elke arm", hy kon "onbreekbare afsitte" in die leivoor spit, rosyntjies omkeer en katoenbale toewerk (p. 77). Sy onthou haar pa se mense as "... oop en maklik leesbaar soos 'n boek wat met oop blaaie lank in die son en wind gelê het' (p. 84; kursiverings - SM).

Hoewel die rivier as die behoud van diegene op sy oewers uitgebeeld word, word vroeg in die bundel ook gesê: "En hy sal oor jou heers" (p. 4). Elders word iets van hierdie groter en meer komplekse omvang van die verhouding tussen mens en rivier weergegee met: "En oor alles hou Eyn-Gariep-Grootrivier die wag en die hoogste troef, hy wat die sentrale mag in jou bestaan is" (p. 220-221). Hierdie belewing van oorheers te word deur die natuur 
hoort tuis binne die postkoloniale siening dat 'n gebied nie deur mense besit word nie, maar dat mense deur 'n gebied besit word (Ashcroft et al., 1998:180). Tussen versorg te word en oorheers te word, beleef die riviermens in Met ' $n$ eie siekspens dus verskillende aspekte van koestering en verknegting; 'n ervaringspektrum waarin elemente van 'n koloniale sowel as 'n postkoloniale plekbelewing12 vasgevang is. In die volgende afdeling word gewys op ander aanduidings dat die bundel ook gelees kan word in terme van 'n postkoloniale sin van plek, alhoewel die gegewe van die afhanklikheid van die natuur strook met die uitbeeldings in die tradisionele plaasroman.

\subsubsection{Verhouding van stryd}

Van Rooyen kyk tegelykertyd met 'n verkyker en 'n vergrootglas na die rivierwêreld van haar herkoms. Sy beskryf die bevreemdende afstandswaarneming toe sy die eerste universiteitsvakansie van Stellenbosch weer terugkom en haar mense en hulle oewerbestaan gerelativeer sien, “... verkneg tot 'n lewe van godsonmoontlike swaarkry langs 'n ontembare oerstroom" en "... uitgelewer aan die swaarste arbeid en die grootste rampspoede denkbaar" (p. 3). Die aspekte van verknegting en aftakeling wat hier aan arbeid gekoppel word, lei tot 'n ondermyning van die verheerliking van arbeid, soos in die vroeë Afrikaanse plaasroman aangetref is (Coetzee, 2000:11). Die rugbreek-arbeid om uit Grootrivier se waters 'n bestaan te maak, impliseer verder 'n proses van onderwerping aan die natuur, in stryd met die koloniale opvatting dat die mens die natuur aan hom onderwerp (Coetzee, 2000:12): "Die sleep van nuwe grond is 'n onmenslike taak ... Waar hoogwater sedert die skepping heerskappy voer en kameelboomreuse diep in sandduine wortel, loop en beur die nietige mense met sy nog nietiger skraper en sy spannetjie trekdiere" (p. 26).

As student wonder die skrywer vanuit die nuwe perspektief wat afstand bring: "Wil hierdie landstreek ooit mense in hom hê, of probeer hy hulle knaend uitwerk met sy onstuitbare hoogwaters en sy moddervrot staanwaters, met sy dikduister stofstorms, sy

12 Binne postkoloniale skryfwerk is plek die term wat verwys na dit wat tot stand kom wanneer "ruimte", 'n neutrale of "leë" punt vanwaar die koloniale diskoers die omgewing waarneem, betekenis verkry deur middel van kulturele inskripsie in die prosesse van benoeming, interpretasie en storievertelling (Ashcroft et al., 1995:391-393; Darian-Smith et al., 1996:3). "Plek" is dus 'n ruimte waaraan betekenis toegevoeg is deur ' $n$ verskeidenheid prosesse van menslike interaksie (Viljoen, 1998:76). 
bloedige hitte en bose plae?" (р. 3). Aan hierdie ervaring van stryd met en ondergeskiktheid aan die rivierlandskap word ook elders uitdrukking gegee in die bundel: "En daar is Grootrivier, wat jou dwing tot onderworpenheid. Hy is nie die verleë, die sterflike ene nie" (p. 236); "[maar] hoeveel sprake van vryheid kan daar wees in 'n landskap waar die elemente die hoogste wette neerlê?" (p. 237).

Die skrywer onthou dat die verknegting destyds soveel swaarder te verduur was weens die element van verknogtheid aan Grootrivier. "Hoe kon ek dan so verskriklik hiernatoe verlang het?" (p. 3) vra sy met haar tuiskoms as student in die riviervallei met sy ongerief en afsondering. Terug in Stellenbosch weet sy: "... hy laat jou nooit los nie, hierdie Adamsland. Na hom sal jou begeerte wees ..." (p. 4). Haar broer, Loet, studeer oor die pos en kom eers vyftien jaar ná skool van Grootrivier weg, om “... daarná sy jare om te hunker en te smag, elke beskikbare tydjie die lang pad aan te pak en daar onder te loop swaarkry vir 'n week of drie" (p. 34).

Uit die skrywer se kindertydherinneringe kristalliseer 'n duidelike belyning van die verhouding tussen mens en rivier: een waarin Wybenga (1994:9) die menslike tragiek sien van "hunkering na die einste wêreldlike woning wat oor hom heers, dikwels genadeloos, waarin hy verdwerg raak en byna vernietig". Die skrywer begryp ook dat hierdie tweespalt in die belewing van die rivierwêreld terugsny na die kwessie van herkoms. ${ }^{13}$ Daar word melding gemaak van haar pa se Nederlandse herkoms (p. 19, 20), sowel as van die stamvader aan moederskant, Charles Marais, se Franse wortels (p. 7, 11). Dit vorm 'n eksplisiete konteks vir die nageslagte se belewing van Grootrivier:

Ma sugsê: 'Ai, hierdie ou stuk wêreld'. Asof sy nog 'n kollektiewe geheue sou kon hê van die matige klimaat in die vrugbare moerasse van Le Plessis Marle in die vaderland van die Hugenote (p. 141).

Opsommend kan gesê word dat die noue verbintenis van mens en rivier wat in Met 'n eie siekspens uitgebeeld word, spruit uit 'n

13 Herkoms/afkoms speel dikwels 'n belangrike rol in identiteitsvorming. Coetzee (1996:49) voer aan dat identiteit "verband (hou) met ontstaan, met genealogie en met die vaste sekerheid van 'n spesifieke begin." Todorov, aangehaal deur Taljard (2002:33), stem saam dat die voorstelling wat 'n mens vir hom-/haarself van die verlede maak, belangrik is vir die konstruksie van persoonlike identiteit sowel as kollektiewe identiteit, aangesien die mens direkte erkenning vir sy bestaan vind in die deelwees van 'n groep. 
bestaansafhanklikheid van die rivier. Verder blyk dit 'n intens teenstrydige verhouding te wees: een van aanhanklikheid en hunkering, wat pas binne die koloniale uitbeelding van mens en natuur, sowel as een van stryd en verknegting, waarin elemente van postkoloniale belewing gevind word. Met die aard van die verhouding tussen mens en rivier vasgestel, kan vervolgens met groter begrip gekyk word na die vormende invloed wat die rivier op die oewermense se identiteit het.

\subsection{Modellering: lewenswaardes as identiteitskomponente}

Teenoor die skrywersgerigte kragte, dié van herinnering en nostalgie, is ook die krag van modellering in goeie outobiografiese geskrifte aan die werk (Venter 1995:12). Namate hierdie krag werksaam word, verdwyn die gestalte van die skrywer, en die persoonsgebonde herinnering word vervang deur 'n kunstenaarsvisie. Wat dan vertel word, dien nie meer bloot die eie herinnering of sentiment nie, maar konkretiseer 'n stel lewenswaardes waarvoor die jeugwêreld die model is. Eers wanneer dit gebeur, word die outobiografie 'n teks met 'n digte betekenisstruktuur (Venter, 1995:12).

In retrospeksie beskou, word Grootrivier se rol as leermeester vir die skrywer duidelik. Hierdie aspek word herhaaldelik beklemtoon in sinne wat begin met: "Grootrivier leer jou ..."; "Veral leer hy jou ..."; "Jy leer ..."; "En jy leer ..."; "Onbewus leer jy ..." (p. 236). Wat geleer word, is "lewenskunde" en die skrywer vermoed "... dis dié soort kennis wat jou volledig moet kom maak" (p. 231).

Eerstens leer Grootrivier dat daar 'n oorsaaklike verband is tussen verlede en toekoms.

Jy ... leer dat 'n toekoms nie wat werd kan wees sonder 'n verlede nie. Want hier het elke ding sy wortels. En jy leer om daardie wortels te voed en te koester as jy wil oes (p. 236).

In hierdie les van die rivier, soos deur die skrywer in haar herinneringe teruggevind, vind ' $n$ mens elemente van Paul Ricoeur se siening oor identiteit, naamlik dat identiteit ten nouste gemoeid is met ons vermoë om te onthou, om die verlede te ken (Ricoeur, 1988:246). Vir Ricoeur is persoonlike identiteit narratief van aard: om te verstaan wie ons is, is om daartoe in staat te wees om ons stories te volg. Een van die belangrikste aspekte van narratiewe identiteit is vir Ricoeur die "historiese narratiewe", die vertellings oor die verlede - hetsy ' $n$ individu se persoonlike geskiedenis of 'n kollektiewe geskiedenis van 'n groep (Ricoeur, 1988:244-249). Dat 
die skrywer in die vormingsproses langs Grootrivier gelei word om die verband tussen identiteit en geheue - die "koester(ing)" van die "wortels" - te begryp, blyk uit die beklemtoning van haar skatpligtigheid teenoor soveel ander mense wat die stories en tye help onthou (p. 5, 6, 12, 13, 19).

Die rol van Grootrivier in die vorming van haar identiteit word in breë trekke deur die skrywer herroep wanneer sy in haar herinneringe tas om 'n profiel van die waardes en lewensbeskouing van haar mense uit die interaksie met die rivier te konstrueer. 'n Lewenswaarde wat sedert kindsbeen langs Grootrivier vasgelê word, is dié van werktoewyding: "Die oewerkind weet hy moet hard werk vir wat hy wil hê. Soms twee keer vir dieselfde ding, en dan kry hy dit op die ou end nie eers nie, as Grootrivier met sy staan- en sy hoogwaters ander sou besluit" (p. 128). Om kragte saam te span in die gesin en gemeenskap blyk van jongs af deel te wees van "... wie en wat jy is ..." op die "... klein miernessies (riviererwe) wat gons en maal en dreun in die oorkoepelende Noordwesterse stilte" (p. 147). Word die grootvoor geskoffel, stuur elke erfhouer 'n paar hande (p. 156). Kom jy 'n buurvrou teë, vra sy nooit: "Hoe gaan dit met jou ma?" nie, maar: "Wat werk jou ma?" (p. 148).

Uit die bestaanstryd teen die rivier groei selfstandigheid en geloof in jouself. "Maar om Grootrivier en sy erflewe te ken, is om enigiets te kán" (p. 233), word gesê, en: "Veral leer hy jou, op die harde manier, dat die beste hulp aan die punt van jou eie arm sit" (p. 236). Die titel van die bundel hou verband met die aanvaarding van verantwoordelikheid vir jou eie situasie. "Elke kiend," het die wyse Jood gesê, "word gebore miet sy eie blêrrie siekspens" (p. 235). Venter (1995:11) interpreteer dit as 'n variant van die Bybelse uitspraak oor die tien talente, maar dan toegepas op die gewone en nugtere bestaan. Van Rooyen self lê in 'n onderhoud die betekenis van haar bundeltitel só uit: "Elke kind word gebore met sekere grondstowwe, sy eie boustof. Daaraan kan hy niks verander nie. Maar hoe hy daarmee bou, is sy eie saak. Jy as mens is mede-opvoeder van jouself" (Nelmapius, 1994:61).

In Met 'n eie siekspens kom die beeld tot stand van 'n mens wat leef volgens 'n orde en volgens die kode van sy wêreld. Menswees op Grootrivier se oewer behels omgee vir mekaar en respek vir almal om jou (p. 97-99); om die beste van 'n slegte saak te maak en klaar te kom met wat jy het (p. 136, 236); asook erns met die opvoedingstaak (p. 99). By wyse van opsomming word gesê: "Alles wat deugde soos arbeidsaamheid, beleefdheid en oppassendheid in die hand werk, is wet" (p. 72). Die hoogste waarde wat gemodelleer 
word, is dié van afhanklikheid van die Skepper (p. 128, 129) en geloof wat Grootrivier jou op 'n baie praktiese wyse leer, byvoorbeeld:

Hoogsomer in ons klipvallei langs Grootrivier is ontsagwekkend ... Dis dan wat jy 1 Konings 19:6 voluit glo: dat 'n engel roosterkoek gaar kan bak op 'n warm klip (p. 217).

Die lewenswaardes wat in Met 'n eie siekspens gekonkretiseer word, spel die moed en waardigheid uit waarmee geleef word ten spyte van ontbering en armoede. Dit is unieke identiteitskomponente verwerf in 'n verhouding van bestaansverbondenheid en -stryd met Grootrivier wat menswees op sy oewers omvattend beïnvloed.

\subsection{Die herlees van die bundel binne die raamwerk van die nuwe herinneringsliteratuur}

Met 'n eie siekspens behels nie die uitbeelding van eensydige nostalgie na 'n paradyslike toestand, of wat die kind-in-diegrootmens as paradys ervaar het, soos in die tradisionele herinneringsliteratuur die geval is nie (Wybenga, 1994:8-9). Dit is pynlike herinnerings aan 'n stryd om oorlewing veral op materiële vlak. Wanneer die geskiedenis van die nedersetting langs Grootrivier vertel word, word gestel: "Die enigste vereiste vir 'n kolonis is dat hy arm genoeg moet wees. En al wat hy hoef saam te bring, is sy twee hande" (p. 5).

Hennie Aucamp (2003:22) skryf dat herinneringsliteratuur in Afrikaans anders geword het in die jare negentig as in die voorafgaande periodes, deurdat dit al hoe meer verbind geraak het met dinge wat bó die individu uitgaan. In die harde finansiële werklikheid sedert 1994,14 waartydens die stryd om 'n inkomste te hê of finansieel óór te begin weer deel geword het van baie blanke Suid-Afrikaners se belewing, kan die leser opnuut assosieer met die uitspraak van die skrywer se ma wat oor haar ervarings langs Grootrivier gepols word en sug: "... Dáárie ou hoofstuk moet jy maar uitlos. Ons het tog te swaar gekry" (p. 5). Kannemeyer (1994:34) sê dat Met ' $n$ eie siekspens deur die uitbeelding van rampe en teleurstellings die regionale vertelling verbystreef en universeel-menslik word.

14 Werkgeleenthede vir die blanke bevolkingsgroep in Suid-Afrika is sedert 1994 drasties verminder weens die regering se beleid van regstellende aksie, indiensnemingsgelykheid en swart ekonomiese bemagtiging (Koekemoer, 1998:33; Booyens, 2001:36). 
Letterkunde is dikwels in krisistye in die geskiedenis van 'n volk sy eie terapie (Aucamp, 2003:25). Met 'n eie siekspens herinner aan swaarkry én aan die oorlewing wat moontlik word vanuit innerlike sterkte. In die gedeelte vóór die titelblad van die bundel word gesê dat die ontberings die mense van Grootrivier geestelik weerbaar sou maak, om te kon "... klaarspeel met die swaarkry". Die geheuebewaring van 'n oorlewingstryd teen die Oranje in die veertigerjare kan dus impetus wees om 'n eietydse geslag deur 'n eweneens moeilike era te help dra. Sonder geheue, sê Aucamp (2003:25), het 'n groep sy identiteit verbeur en sy kollektiewe bewussyn gekanselleer. Waar besielende identiteitsaspekte van 'n vorige geslag uit herinnerings na vore tree, soos in hierdie bundel waar die funksie van herinnering primêr dié van karakterisering is, is die bron van geheuebewaring in 'n latere oorlewingstryd van soveel méér waarde.

Hierdie artikel gaan voort deur aan te toon hoedat dit ook uit Pieterse se roman ewe duidelik blyk dat 'n rivier karakters se identiteit, denke en lewe kan rig, hoewel daaraan op 'n heeltemal andersoortige literêre wyse gestalte gegee word as in Van Rooyen se bundel.

\section{Manaka: plek van die horings}

John (2005:15) meen tereg dat Pieterse se laaste roman 'n hersiening afdwing van die leser se vooropinstelling en verwagtings van gemoedelike kampvuurstories wat geskoei is op vorige ontmoetings met dié skrywer in die "werfjoernale" waarin hy Bosveld-, Skedelkus- en Weskusstories vertel. Die verhaal van Manaka: plek van die horings wentel om die pogings van die hoofkarakter, Dennis Chipman, oftewel "Baas", om rigting aan sy lewe te gee deur 'n toerisme-onderneming te ontwikkel op 'n afgeleë gedeelte van die Zambezi in Barotseland in Zambië.

Hoewel Pieterse se oeuvre gekenmerk word deur die uitbeelding van die mens se saambestaan met die natuurdinge (Van Zyl, 1985:12; Weideman, 1989:8), is Manaka: plek van die horings uniek daarin dat die kwessie van identiteit hier verweef is met die mensnatuur-verhouding. In vorige werke vorm die rivier soms reeds die fokuspunt in terme van ruimtelike situering. 15 In Manaka: plek van

15 Winterwerf in die Kavango (1989) en Hande klap vir Afrika (1996) vertel van die skrywer se verblyf langs die Kavango- en Kwandoriviere in die noordelike uithoeke van Namibië onderskeidelik. Die jeugverhaal $\mathrm{Om}$ 'n kierie te keer (1998) handel oor 'n seun van die Mafwe-stam langs laasgenoemde rivier en Anderkant die groot rivier (1990) speel langs 'n Bosveldrivier af. 
die horings word die rivier 'n sentrale mag deur die vormende rol wat dit speel ten opsigte van die hooffiguur se drome en identiteit.

\subsection{Zambezi: die begin en einde van 'n droom}

\subsubsection{Die rol van die rivier in die vorming en bevestiging van identiteit}

Dennis Chipman, noemnaam Baas, is die vierde generasie Chipmans en sy verhaal behels die soeke na sy oupagrootjie se standplaas teen die Zambezi, Manaka, asook sy droom om hierdie grootjie se ideaal van vaartuie op die Zambezi te verwesenlik. Hierdie ideaal oorheers reeds sy lewe as kind: in 'n selfgemaakte blikskuit leer hy op 'n plaasdam roei en toets die boot tydens die reënseisoen op die waters van die Bo-Letabarivier (p. 10);16 hy bring ure deur met leesstof oor Zambië en die Zambezi (p. 11) sowel as met topografiese kaarte oor Barotseland en ander gebiede teen die Zambezirivier (p. 15). Sy identiteit is op 'n vroeë ouderdom reeds vervleg met hierdie rivierdroom, hy "voel ... dikwels dat hy met elke tree in die spoor van sy oupagrootjie trap" (p. 11). Die kwessie van selfsiening funksioneer in hierdie roman baie sterk in die uitbeelding van identiteit.17 Tot watter mate die Zambezi en Baas se siening van selfrealisering by wyse van die bereiking van hierdie rivierdoelwit hom dryf, blyk uit die ervaring van "ongedurigheid" in sy werk en die bedanking wat daarop volg (p. 15). Hy beland as bootsman op die vaartuig van 'n mede-Suid-Afrikaner op die samevloeiing van die Zambezi en Choberivier, wat hy 'n ruk later koop met die idee om dit in 'n pontboot vir toeriste te omskep (p. 38).

'n Belangrike aspek van sy grootjie se droom was die kartering van die Zambezi (p. 9). In navolging hiervan hou Baas op sy vaart noordwaarts in die Zambezi 'n notaboek aan waarin hy "sketse" (p. 25) en "noukeurige aantekeninge" (p. 26) maak van die stroomversnellings, systrome, sandbanke en ander hindernisse wat die bevaarbaarheid van die rivier beïnvloed. In hierdie werkwyse is die

16 Verwysings in punt 3 en onderafdelings wat bloot met 'n bladsyverwysing aangedui word, verwys na Pieterse (2005).

17 Erikson (1980:71-72) sien 'n direkte verband tussen identiteit en 'n persoon se selfbeeld, die "mental model of him or herself", waarna verwys word as persoonlike identiteit. 
"imperial eye"18 herkenbaar, die inpalming en toe-eiening by wyse van kartering en beskrywing, waardeur die Zambezi-wildernis "makgemaak" word in die sin om dit toegankliker te maak vir die toerismebedryf, soos die begeerte reeds was by die eerste Dennis Chipman (p. 8).

Hierdeur word die kwessie van besitterskap sentraal gestel ten opsigte van persoonlike identiteitsbelewing. Geplaas binne die postkoloniale diskoers is Baas verpersoonliking van die koloniseerder se aandrang op eienaarskap, wat in die tradisionele Afrikaanse plaasroman gestalte kry in die boer se verbondenheid met sy grond. Die boer se identiteit is slegs te vinde in sy verwantskap met die grond, maar hierdie selfverwesenliking is verbind aan besitterskap (Coetzee, 2000:13). Nadat Baas op Manaka gearriveer het, maak hy dadelik 'n afspraak met die indoena-owerheid van Senanga vir woonregte op die gebied (p. 2324), wat herinner aan die optrede van die patriargvoorvader in die vroeë Afrikaanse plaasroman wat sy plaasgrense oprig en dan 'n grondbrief van die naaste landdros kry om sy eienaarskap te bevestig - die sogenaamde vestiging van die "territorial imperative" binne 'n vreemde gebied (Van Heerden, 1999:4). Baas verklaar: "Ná twee-en-negentig jaar het Manaka weer 'n Chipman vir 'n baas" (p. 40). Die betekenisvolle noemnaam "Baas" is dus bevestigend van die intensie om eienaarskap oor die gebied uit te oefen en hou verband met die kwessie van patriargale besit en die oordra van eiendom deur opeenvolgende geslagte. Aan die ou sendeling, oom Scholtzie, word verduidelik: "My naam is Baas. Dis nie 'n titel of iets nie ... Ek het dit van my geboorte af en ek het dit geërf. Van my oupagrootjie af het dit deur die geslagte af gekom tot by my" (p. 114). Hier is sprake van dubbele erfopvolging: die eerste Baas Chipman het die stuk grond wat Baas opeis lank tevore reeds makgemaak vir bewoning, en daarmee 'n natuurlike reg op besit van die grond vir die nageslag verewig (vgl. Coetzee, 1988:85). Maar ook die naam Baas as bevestiging daarvan dat die patriarg sy grond beskou as "koninkryk" waar hy alleenseggenskap het (vgl. Lubbe \& Wiehahn, 2000:156), is geërf.

Die oprigting van plaasbakens of -heinings is 'n gebaar met behulp waarvan die patriarg sy onafhanklike voortbestaan op ' $n$ vreemde en ongetemde vasteland sou waarborg (Coetzee, 2000:13). Die mees boek Imperial eyes: travel writing and transculturation en verwys na die gierige aftas en inpalming van nuwe gebiede deur die oog van die koloniseerder. 
konkrete bevestiging van "baasskap" deur afbakening word gevind in die vaskap van trofeë aan die stamme van die oewerbome rondom die kamp, 'n praktyk wat aan die eerste Dennis Chipman se blyplek die naam "Plek van die horings" besorg het (p. 7-8) en wat deur Baas nagevolg word (p. 201, 203). Met behulp van die rivier en sy bootplanne vind Baas dit dus moontlik om 'n bepaalde aspek van sy identiteit, naamlik sy patriargale wil om baas en besitter van die gebied te wees, te bevestig.

Die begeerte tot besitterskap staan, soos by baie identiteitsgekoppelde kwessies die geval is, waarskynlik nie los van die ervarings uit die verlede nie. Baas is 'n slagoffer van die onafhanklikheidsoorlog in Zimbabwe: sy ouers is deur terroriste vermoor en hy het al sy familiebesittings, insluitende die plaas, verloor (p. 13). Vanuit hierdie bepaalde agtergrond is Baas besiel met ' $n$ ywer vir sy Zambeziideaal wat hom spoedig in konflik bring met die medegebruikers van die rivier, die mense van die Lozi-stam wat uit die vrugbare landbougrond op die vloedvlaktes van die Zambezi leef en van meet af beslag lê op die tyd en energie wat hy aan die boot wou spandeer.

Vervolgens word ondersoek ingestel na elemente van teenstand, almal verbandhoudend met die toestande langs die Zambezi, wat die aanspraak op "baasskap" in die wiele ry en die besef tot Baas laat deurdring dat sy werklike identiteit méér behels en dat hy sy lewensdoel verkeerd verstaan het. Daar sal dus uitgewys word hoe die postkoloniale diskoers in hierdie roman teenstand bied teen die aanspraak op dominansie ("baasskap") en besit.

\subsubsection{Baas se "baasskap" in die wiele gery}

Baas word baie gou betrek by die nimmereindigende behoeftes van die riviermense wat deur malaria geteister word (p. 28, 43, 63), oor feitlik geen vorm van vervoer beskik nie en verwag dat hy ook kos sal voorsien (p. 37). Ouma Essie verklaar dankbaar dat sy weet die tyd het gekom "... dat iemand gestuur word om die mense van Manaka te help" (p. 43); daarom stroom die siekes na Manaka (p. 62,63, 185) en moet hy kos weggee aan dié wat nie in die ry van vleiskopers kan staan nie (p. 91, 125, 145). Die khuta herinner hom aan sy "verpligtinge teenoor die stam" wat nagekom kan word deur "... sy lewensmiddele tot die beskikking van die mense te stel" (p. 56). Weldra verneem Baas ook dat die khuta 'n aandeel verwag in die wins op die vleis wat hy verkoop sowel as wat deur die boot ingebring sal word, omdat die konsessie wat vir verblyfdoeleindes aan hom toegestaan is, nou "... ook as besigheidsperseel gebruik 
word" (p. 168). Hierdie aansprake kan, binne die konteks van die Afrika-wêreldbeskouing van Ubuntu,19 geïnterpreteer word as die verwagting dat Baas sy gemeenskapsbetrokkenheid behoort te toon deur die uitlewing van konsiderasie, deernis, behulpsaamheid en vrygewigheid (vgl. Broodryk, 2004:55).

Baas reageer vanuit die staanspoor gebelgd op al hierdie eise en sy ergernis verraai die kolonialisties-meerderwaardige manier waarop die "ander" waargeneem en hulle behoeftes ondergeskik gestel word (vgl. Van Zyl, 2002:175-176). Hy sê: "Om gaaf te wees, kry nie 'n boot op die water nie" (p. 92) en: "Hoekom dink jy lê die materiaal om my boot reg te maak vir byna 'n jaar onder die plastiekseile en vrot? ... Dink jy ek het Barotseland toe gekom om verantwoordelik te voel vir almal se skete en kwale en hongersnood?" (p. 63). Nadat die laaste fondse uit Baas se bankrekening onttrek is om weereens malariamedisyne te koop (p. 64) en die aansprake om hulp steeds inrol, ontplof hy: "Ek wil ook nie weet van werksoekers en ... kruppel vrouens en sterwendes wat met 'n slee na my toe aangery word nie" (p. 93). Hy jaag ouma Essie weg (p. 43), doen dieselfde met Grace (p. 93) en vloek op die khuta (p. 87).

As hierdie konflik gelees word binne die konteks van die postkoloniale diskoers, bied Wasserman (2000:40) perspektief daarop: omdat sowel koloniseerder as gekoloniseerde 'n bepaalde ruimte deur verskillende prosesse van kulturering tot plek kan verander, verteenwoordig plek 'n troop van konflik. Die Lozi-mense sien Manaka as 'n plek waar om hulp aangeklop kan word, in navolging van die medemensgerigte Ubuntu-beginsel; vir Baas is Manaka die sentrum van sy persoonlike belang en "heerskappy".

Terwyl sy tyd, geld en fokus weggesteel word van die droom wat sy lewe tot hier toe gerig het, sukkel Baas self met malariasimptome. Kort nadat hy op Manaka aangekom het, beland hy in die hospitaal en lank daarná voel hy steeds liggaamlik te afgetakel om te vorder met die noodsaaklike werk aan die boot (p. 85, 111). Verdere probleme vir Baas is die vrees dat die stygende watervlak van die rivier met die reënseisoen sy werk aan die boot gaan begin bemoeilik (p. 85, 159), asook die feit dat die sendelinge se koms vir talle verdere onderbrekings sorg (p. 183, 201). Ouma Essie paai dat wêreldbeskouing wat in 'n gees van welwillendheid beleef word, gebaseer op die universele primêre waardes van intense menslikheid, opregte omgee, onbaatsugtige mededeelsaamheid en natuurlike respek. 
die sendelinge moes kom om ter wille van die sieleheil van die Lozimense in te gryp (p. 167, 170). Vir Baas het die mense langs die Zambezi en hulle aansprake en behoeftes 'n onoorkomelike struikelblok geword in die verwesenliking van die droom waarrondom sy lewe gebou is. Terwyl die rivier die stukrag is agter die lewensideaal waarin so 'n groot deel van sy identiteit verknoop lê, lewer dieselfde rivieromgewing ook 'n kwota probleme - malariamuskiete ingesluit wat hom sy sorgvuldig beplande lewensmoontlikhede en ook mettertyd sy moed ontneem. Wanneer die boodskap kom dat sekere onderdele vir die boot nie verkrygbaar is nie, sê hy: "Ek het dit nie meer nodig nie" (p. 173).

Deur die gegewe rondom die boot se verdwyning word gesuggereer dat die stryd om "baasskap" hier tot 'n hoogtepunt gevoer word in die subtiele magstryd tussen Baas en toordokter Chisupo. 20 Baas se handlanger, Johnnie, verduidelik waarom nie Baas óf die sendelinge welkom is in Chisupo se "gebied" nie: "... want hy weet hulle vat sy krag weg" (p. 108). Die toordokter se gramskap teenoor Baas blyk in verband te staan met laasgenoemde se duidelike intensie om die gebied aan sy rivierideaal te onderwerp, en die boot te gebruik as 'n middel tot die doel van "baasskap". Dit word gesuggereer deur die feit dat dit nie Baas se blyplek is wat deur Chisupo vernietig word nie - soos in die geval van die sendelinge maar die boot wat losgesny word. Die rivier doen die res en die boot is weg (p. 230).

In hierdie afdeling is geargumenteer dat Baas se droom om 'n toerboot op die Zambezi aan die gang te kry ook die wyse is waarop hy poog om homself as mens te realiseer. As sodanig is dit deel van sy identiteit - dit is ten diepste 'n begeerte om baasskap, die wil om die omgewing te "tem" (p. 174) en dus vergestalting van die pioniersdrang en koloniale dominansie. Ook is bevind dat die malariabesmette omgewing en die inwoners daarvan verskillende troefkaarte speel om hom in sy planne te stuit - 'n ondermyningsproses wat aansluit by die postkolonialiteit van die roman. In die laaste afdeling sal gefokus word op die gebeure en proses waardeur Baas 'n breër begrip verkry van wie hy werklik is en wat sy lewensrol is. Dit sal duidelik word dat 'n nuwe, postkoloniale

20 Die "donker skaduwee" van Chisupo se teenwoordigheid net buite Baas se kamp (p. 76, 143, 148, 227) en in gesprekke met Johnnie en ouma Essie (p. 77, $93,108,149,163$ ) het vir ondertone van onheil in die roman gesorg. Wanneer Baas en Grace op die plek staan waar die boot losgesny is, sê sy dadelik: "Dit is waar meneer Chisupo was" (p. 231). 
identiteit gevorm word binne 'n nuwe siening van die verhouding tot die grond en die ander bewoners daarvan.

\subsection{Herbesinning oor lewensdoel en identiteit}

Terwyl Baas se planne met die boot rondom sy eie belange ontwerp is, glo sowel ouma Essie (die "profeet van die Bybel") as haar kleindogter, Grace, dat Baas om 'n heeltemal ander rede "gestuur" is as die doel wat hyself voor oë het. "As die Here ... vir jou kom sê het jy gaan nie van hierdie siekte gesond word nie en daar is net één ding wat jy nog kan kies om klaar te maak ... sou jy die boot gekies het?" daag Grace (p. 63). Baas weier aanvanklik om homself in die identiteitsrol van gestuurde-van-die-Here te sien: “... ek is nie gestuur nie en ek is ... nie hier om enigiemand te kom help nie" (p. 43); "Ek is nie in Barotseland om welsynswerk te kom doen nie" (p. 126).

Die laaste fase in die kortwiek van Baas se ideaal en die ondermyning van sy aanspraak op "baasskap" breek aan met die wegvoer van die boot, waarin die rivier mede-"aandadig" is. Wat hier voltrek word, is die finale omkering van rolle: die Zambezi en die "komplot" van verbandhoudende omstandighede is 'n krag waardeur Baas tot onderworpenheid gedwing word, terwyl Baas eintlik die rivier aan sý ideaal wou onderwerp.

Ontneem van sy boot pak Baas nou 'n ander taak aan: die bou van bankies onder die worsboom teen die rivier (p. 244-245). Vroeër het hy heftig teenstand gebied toe die sendelingsvrou bankies onder die worsboom wou bou vir die kinders (p. 111); hierdie boom is die plek wat hy gekies het om die boot te herbou (p. 36) en die sitplekke wat met sy koms daar was, het in die slag gebly om vir die boot plek te maak (p. 40). Sy nuwe doelwit, aanduidend van 'n verbreding in sy siening van homself en sy taak, sluit aan by dié van sy oupagrootjie wat oorspronklik die bankies onder die worsboom gebou het om 'n skooltjie en kerk vir die plaaslike mense te bied (p. 8) en só die sending-"plantjie" op Manaka geplant het (p. 117-118). Die nuwe aktiwiteit dien as duidelike afsluiting van die gerigtheid op 'n bepaalde lewensdoel - juis onder die worsboom staan Baas en kyk na die kaal pale en afgekapte toue van sy boot se stellasie teen die nagtelike luglyn (p. 235) - en die oopgooi van sy slaapsak onder die worsboom waar sy voorsaat Manaka Evangelical Mission (p. 245) gestig het, kan as simbolies van sy toewyding aan 'n nuwe ideaal gelees word. Elemente van 'n nuwe, postkoloniale identiteit is ter sprake waar Baas hier die rol aanvaar van onderworpene, diensbaar aan die gemeenskap eerder as patriargale oorheerser daarvan. 
Baas verraai hiermee saam 'n veranderde ervaring van Manaka, wat hy vroeër as plek van sý droom en verlengstuk van sy eng beleefde identiteit as baas en booteienaar gesien het. Hoewel ouma Essie daarop aanspraak maak dat Manaka die plek is waar "... die Here van altyd af ... met sy mense gepraat het ..." (p. 115), was Baas aanvanklik kwaad toe die khuta die boonste gedeelte van Manaka aan die sendelinge verhuur (p. 85-86). Gestroop van sy selfgerigte ideaal dra hy nou die buffelhorings teen die bult uit en slaan dit vas bokant die naambord - Manaka Evangelical Mission - wat iemand intussen weer aan die paal vasgesit het (p. 136). Dit is konkrete bevestiging dat hy sy plek uitbrei na die boonste helfte waar die kerk herbou gaan word. Hy erken ook sonder protes ontvangs van die boumateriaal wat vir die kerk afgelewer word (p. 244). Manaka is nie meer sentrum van patriargale oorheersing nie, maar plek van geestelike versorging vir die gemeenskap. Vir die eerste maal blyk die betekenisvolheid van evangelis Joseph se lyfband wat ouma Essie hom kort ná sy aankoms aanbied en wat perfek pas (p. 121). Baas neem die taak van versorging van 'n geestelike kudde oor van die ou evangelis.

Die duidelikste teken van 'n nuwe soort gewilligheid om sy identiteit in 'n breër familiekonteks te sien, blyk ook uit die gedagte wat Baas te binne skiet ná die rivier die boot weggevoer en die kerk afgebrand het: "Wie weet of jy nie met die oog op 'n tyd soos hierdie Manaka toe gestuur is nie? het ouma Essie gesê. Is dit dalk ook hoe die familiekwaal werk waarvan Whitey gepraat het?" (p. 234). Hierdie "kwaal" blyk uit dieselfde gesprek met Whitey waaruit Baas hulle verwantskap ontrafel - die buffeljagter is albei se grootjie: Whitey stam uit sy verbintenis met die Lozi-vrou, Tibeleo; Baas uit die huwelik met Johanna Smit nadat Chipman teruggekeer het na SuidAfrika (p. 177, 226). "Ek help mense omdat ek daarvan hou, nie omdat ek iets terug verwag nie," verduidelik Whitey, "dis 'n familiekwaal" (p. 178). Heelwat vroeër het ouma Essie reeds by Baas die "kwaal" van jammerhartigheid en betrokkenheid gediagnoseer toe hy homself in woedende terme probeer distansieer het van die siektes, honger en werkloosheid rondom hom en sy hom moes herinner: "Dis nie ek wat jou die oë gegee het waarmee jy al hierdie dinge sien nie" (p. 93). Onderliggend aan die groter duidelikheid omtrent sy eie identiteit lê 'n pas afgehandelde geloofstryd rondom die vraag: "Wat maak van jou 'n Christen?" (p. 146), waarop Grace hom 'n eenvoudige antwoord gee: "Omgee ... Dis sendingbloed" ( $p$. 228). Nadat hy by almal rondom hom na 'n antwoord op hierdie vraag gesoek het (p. 138, 146, 155, 202) blyk iets van die aanvaarding van die rol van gestuurde uit die berustende gebed wat 
hy teen die einde van die roman by ouma Essie se siekbed bid: "Dankie, Here. Amen" (p. 243).

In die uitbeelding van Baas se aanpassing by 'n meer omvattende siening van sy taak en identiteit is die rol van drome betekenisvol. Ouma Essie vra Baas kort ná sy aankoms uit oor sy plan met die boot en sy sê: "Die drome wat die kinders van die Here droom, is die drome wat Hy vir hulle géé om te droom" (p. 122). Daarop reageer Baas verontwaardig: "So romanties is dit nie, ouma Essie. Die boot moet my aan die lewe hou." Tog herroep hy die ou "profeet" se woorde in verband met die droom wat die Here Sy kinders gee later baie duidelik (p. 203). Wanneer die rivier die boot as't ware oornag insluk sodat geen teken daarvan gevind kan word nie, bring Whitey die tyding: "Ek het gedroom jou boot dryf in ons oupagrootjie se kanaal langs die waterval verby" (p. 245). Hierdie kanaal kan geassosieer word met verydelde drome: dit is ontwerp om die Ngonye-waterval te omseil sodat Chipman die Zambezi vir sy boot kon "tem", maar malaria en omstandighede het hom verhoed om ooit self die kanaal te benut (p. 174). Met Dennis Chipman se terugkeer na Suid-Afrika was hy siek en arm, ontdaan van die siening van homself as oorwinnaar, maar hier het sy lewe nuwe rigting gekry met sy huwelik en die geboorte van 'n seun (p. 9). Wanneer Baas se boot in hierdie kanaal indryf, word die moontlikheid van 'n óórbegin en 'n gewysigde doel en droom in die leser se gedagte gelê.

Die rivier speel ten laaste ook ' $\mathrm{n}$ rol in die bekragtiging van Baas se nuwe identiteitsbesef en lewensvoornemens op die vlak van praktiese besluitneming. Deur die boot as't ware "terug te gee" (nadat Baas by die waterval besef het hy sal nie eens splinters daarvan terugkry as die boot daaróór is nie (p. 232)), word hy 'n finale keuse gebied omtrent sy toekoms. Sy besluit word duidelik uit die belangelose hantering van sy broer se brief - die nuus dat reisagente oormekaar val om sy toerboot te bemark (p. 233) asook die gesprek met Grace oor die aanspreekvorm "meneer" Baas toe sy hom met die mukolo na die vasgespoelde boot neem (p. 246). Hoewel Grace hom daarop wys dat hierdie aanspreekvorm die gebruik is onder haar mense om eerbied teenoor ' $n$ meerdere te betoon, dring hy aan: "Sê net 'Baas'. Dit is wat my naam is". Daarmee doen hy finaal afstand van die rol van meerdere in die benutting van die rivier tot sy eie uitsluitlike voordeel.

Die naam en identiteitsmerker "Baas" word hier met 'n nuwe betekenisinhoud gevul. Baas gaan haal die boot en dra weer sy geweer oor sy skouer. Hy sien homself dus steeds in die rol van 
helper en versorger deurdat hy, soos vroeër, die voorsiening van vleis en moontlik ook nou riviervervoer en 'n sendingbediening met behulp van die Zambezi Grace op hom neem, maar dit is nie meer blyke van patriargale sorg oor onderdane nie. Dit blyk veel eerder die vergestalting te wees van die Ubuntu-konvensie om wanneer 'n mens het, besittings spontaan met ander te deel (vgl. Broodryk, 2004:72). Daar is dus tekens van vereenselwiging met die woorde van die sendeling: "Christenskap is 'n gesindheid ..." (p. 155), wat ná hulle gesprek in Baas se gedagtes bly (p. 207). Hierdie nuwe gesindheid impliseer dat Baas geen woede of verset meer openbaar teen die versorgings- en onderskragingsrol waarin die belange van die Zambezi-mense voorop gestel word nie.

Met die redenasie in hierdie afdeling is betoog dat daar uit die veranderde verhouding tot die rivier, die grond waarop hy woon en die mense wat dit met hom deel 'n nuwe, postkoloniale identiteit vir Baas tot stand kom.

\section{Samevattend}

Met 'n eie siekspens en Manaka: plek van die horings vorm twee duidelike stemme in die literêre vergestalting van die tema van die rivier as beïnvloeder van menslike lewe en identiteit. Die karakters se verhouding van afhanklikheid en aanhanklikheid van die rivier word in dié tekste verskillend gemotiveer: in eersgenoemde teks gaan dit oor 'n bestaansafhanklikheid waarin die elemente van verknogting bots met dié van verknegting; uit die tweede teks blyk die bepalende rol van die rivier ten opsigte van die vestiging en verbrokkeling van toekomsideale waarrondom 'n hele lewe gebou word. Hierdie ondersoek werp veral lig op die wyses waarop die inspeel van die rivier op die vorming van en die begrip vir karakters se identiteit uitgebeeld word. Die lewenswaardes wat die rivier en rivieromgewing die karakters in Met 'n eie siekspens leer, is kernkomponente van hulle identiteit. In die analise van Manaka: plek van die horings is bevind dat die hoofkarakter se droom oor 'n lewe op die rivier deel is van sy identiteit, deurdat dit sy denke en selfbeskouing sedert kindsbeen rig. Die rivier en omgewing speel egter ook 'n sentrale rol in die latere herinterpretasie van sy lewensdoel en die verkryging van 'n breër begrip van sy ware identiteit.

Albei hierdie werke is postkoloniaal deurdat daar besin word oor die kwessie van dominansie in die mens-natuur-verhouding. In Manaka: plek van die horings word ander postkoloniale kwessies soos 
pionierskap, grondbesit en patriargale oorheersing betrek in die uitbeelding van identiteitskonstruksie.

Hierdie artikel onderstreep die belang van navorsing oor die uitbeelding van die verhouding tussen mens en bepaalde aspekte van die natuurlike omgewing in die Afrikaanse letterkunde. Die ondersoek hoort tuis binne die groter studieveld waarin die uitbeelding van identiteitskwessies as onderwerp gestel word en hanteer ' $n$ leemte wat tans in die Afrikaanse literatuurkritiek bestaan.

\section{Geraadpleegde bronne}

ASHCROFT, B., GRIFFITHS, G. \& TIFFIN, H. 1995. The post-colonial studies reader. London: Routledge.

ASHCROFT, B., GRIFFITHS, G. \& TIFFIN, H. 1998. Key concepts in postcolonial studies. London: Routledge.

AUCAMP, H. 2003. Die beperkte boog van bestaan: gedagtes oor herinneringsliteratuur. Stilet, XV(2):20-27.

BLIGNAULT, A. 1996. Siekspens 'n aangrypende vertelling. Die Volksblad: 7, 6 Maart.

BOOYENS, H. 2001. Vat jou pakkie! Insig: 36-37, Apr.

BROODRYK, J. 2004. Oeboentoe. Pretoria: Jetline.

CASTELLS, M. 1997. The information age: economy, society and culture. Vol. 11: The power of identity. Malden: Blackwell.

COETZEE, A. 1996. Oorgangsliteratuurgeskiedenis: die illusie van 'n nasionale Suid-Afrikaanse letterkunde. Literator, 18(3):41-55.

COETZEE, A. 2000. 'n Hele os vir 'n ou broodmes: grond en die plaasnarratief sedert 1595. Pretoria: Van Schaik.

COETZEE, J.M. 1988. White writing: on the culture of letters in South Africa. New Haven: Yale University Press.

DARIAN-SMITH, K., GUNNER, L. \& NUTTAL, S. 1996. Text, theory, space, land, literature and history in South Africa and Australia. London: Routledge.

DU TOIT, P.A. 1997. Verhaal reik wyer as sy Sotho-agtergrond. Die Volksblad: 6, 5 Mei.

ERIKSON, E. 1980. Identity and the life cycle. New York: Norton.

JOHN, P. 2005. Nagelate "Manaka" 'n verrassend ryk teks. Beeld: 15, 14 Nov.

KANNEMEYER, J.C. 1994. Só 'n "siekspens" is nie 'n tiekie 'n bos nie. Rapport: $34,31 \mathrm{Jul}$.

KOEKEMOER, L. 1998. Affirmative action: a force of empowerment or threat? Aambeeld: 31-33, Jun.

LOMBARD, J. 1999. Waterslangverhale in en rondom Afrikaans: 'n ondersoek na mitisiteit as basis vir vergelykende literatuurstudie. Potchefstroom: Noordwes-Universiteit. (Ph.d.-proefskrif.)

LUBBE, H. \& WIEHAHN, R. 2000. Die Afrikaanse plaasroman in die twintigste eeu. Stilet, XII(2):153-165.

MALAN, L. 2004. 'n Geskakeerde bydrae tot herinneringsliteratuur. Literator, 25(1):189-191.

MARTIN, D-C. 1995. The choices of identity. Social Identities, 1(1):5-21. 
NELMAPIUS, K. 1994. Ongeduld is haar stukrag: Van Rooyen praat oor inspirasie en laaste boek. Rooi Rose: 61-62, 24 Aug.

PIETERSE, P. 2005. Manaka: plek van die horings. Kaapstad: Human \& Rousseau.

PRATT, M.L. 1992. Imperial eyes: travel writing and transculturation. London: Routledge.

RICOEUR, P. 1988. Time and narrative. Vol. 3. Vertaal deur K. McLaughlin \& D. Pellauer. Chicago: University of Chicago Press.

SCHEESE, D. 2002. Nature writing. New York: Routledge.

SMUTS, J.P. 1997. Die nuwe herinneringsliteratuur in Afrikaans. Stilet, IX(2):18.

SMUTS, J.P. 2000. Die einde van die millennium: vier jaar Afrikaanse prosa. Stilet, X11(2):1-26.

TALJARD, M.E. 2002. Herkoms en identiteit in Die swye van Mario Salviati (Etienne van Heerden) en De naam van de vader (N. Noordervliet). Potchefstroom: Noordwes-Universiteit. (M.A.-verhandeling.)

VAN COLLER, H.P. \& ODENDAAL, B.J. 1999. Profiel: George Weideman. (In Van Coller, H.P., red. Perspektief en profiel. Band 2. Pretoria: Van Schaik. p. 764-783.)

VAN DER MERWE, B.A.J. 1999. Afrika in die resente Afrikaanse digkuns. Potchefstroom: Noordwes-Universiteit. (Ph.d.-proefskrif.)

VAN HEERDEN, E. 1999. "Afrika" as onvoorspelbare naam - enkele aspekte van die Afrikaanse skrywer se verhouding met die landskap. Tydskrif vir Letterkunde, XXXVII(2):1-11.

VAN MANEN, M. 1999. Verhale tree ligvoets oor grense. Die Burger: 7, 8 Sept.

VAN ROOYEN, E. 1994. Met 'n eie siekspens. Kaapstad: Tafelberg.

VAN ZYL, A. 1985. Uitbeelding bly sensitief en realisties. Die Volksblad: 12, 21 Sept.

VAN ZYL, D. 2002. Base en klase: perspektiewe op en deur die ander in enkele 19de-eeuse Nederlandse en Afrikaanse tekste, met 'n fokus op naamgewing, aanspreekvorme en landskap. Stilet, XIV(1):167-184.

VENTER, L.S. 1995. Boekbespreking: Met 'n eie siekspens. Radiobespreking in program "Skrywers en boeke" uitgesaai op Afrikaans Stereo, 13 Maart 1995. (Opgeneem in die NALN-knipselversameling in Mei 1995.)

VILJOEN, L. 1998. Plek, landskap en die postkolonialisme in twee Afrikaanse romans. Stilet, X(1):73-92.

VILJOEN, L. 2002. "Die kleur van mens": Antjie Krog se Kleur kom nooit alleen nie en die rekonstruksie van identiteit in post-apartheid Suid-Afrika. Stilet, XIV(1):20-49.

WASSERMAN, H. 2000. Terug na die plaas - postkoloniale herskrywing in Etienne van Heerden se Die Stoetmeester. Tydskrif vir Nederlands en Afrikaans, 7(1):29-55.

WASSERMAN, H. 2001. Om hergeboorte te verbeel: 'n postkoloniale beskouing van migrasie, kultuur en identiteit. (In Van Heerden. E., red. Briewe deur die lug: LitNet/Taalsekretariaat skrywersberaad 2000. Kaapstad: Tafelberg. p. 297-308.)

WEIDEMAN, G. 1989. Lekker werfstories. Die Burger: 8, 21 Des.

WHITE, P. 1995. Geography, literature and migration. (In King, R., Connell, J. \& White, P., eds. Writing across worlds: literature and migration. London: Routledge. p. 1-19.)

WYBENGA, G. 1994. Aards en eg nes die Gariep. Beeld: 8-9, 27 Jun. 


\section{Kernbegrippe:}

herinneringskuns

identiteitskonstruksie

Pieterse, Pieter: Manaka: plek van die horings

postkolonialisme

Van Rooyen, Engela: Met 'n eie siekspens

verhouding: mens en natuur

\section{Key concepts:}

construction of identity

Pieterse, Pieter: Manaka: plek van die horings postcolonialism

relationship: human and nature

reminiscing literature

Van Rooyen, Engela: Met 'n eie siekspens 
